\title{
スケトウダラ冷凍すり身構成成分が 加熱ゲルの物性に及ぼす影響
}

\author{
北上 誠一, ${ }^{1 *}$ 村上由里子, ${ }^{1}$ 小 関 聡 美, ${ }^{2}$ 加 藤 $\quad$ 登, ${ }^{2}$ 新 井 健 ${ }^{1}$ \\ (2007 年 6 月 11 日受付, 2007 年 10 月 25 日受理) \\ 1社団法人全国すり身協会, 2東海大学海洋学部
}

Contribution of walleye pollack frozen surimi components to physical properties of heat-induced gel formed from it
SEIICHI KITAKAMI,${ }^{*}{ }^{*}$ YURIKo MURAKAMI, ${ }^{1}$ SATOMI KOSEKI, ${ }^{2}$ NOBORU KATO ${ }^{2}$ AND KEN-ICHI ARAI ${ }^{1}$

\begin{abstract}
${ }^{1}$ National Surimi Manufacturers Association, Abashiri, Hokkaido 093-0057, ${ }^{2}$ School of Marine Science and Technology, Tokai University, Shimizu, Shizuoka 424-8610, Japan
\end{abstract}

\begin{abstract}
The contribution of components in walleye pollack frozen surimi to the heat-induced gel formed from it was investigated. The proximate composition and breaking strength (BS) and breaking strain (bs) of the two-step heated gel formed were measured. The results were as follows: (1) On addition of water (0-125\%) or sugar (0$50 \%$ ) to the surimi, the maximum values of BS and Gs (BS/bs) of the heated gel formed were decreased, although the rate of decrease with sugar was larger than that with water. (2) When the protein concentration in the heated gels was fixed, the increase in sugar concentration from 6.1 to $24.5 \%$ caused the decrease in the maximum value of BS while that of Gs was unchanged. (3) When the concentrations of protein together with moisture in the heated gels were fixed, the reduction in the sugar concentration from 7.7 to $3.7 \%$ in the heated gel did not change the maximum values of BS and Gs. These results indicate that the physical properties of the two-step heated gel can be designed by regulating its proximate composition.
\end{abstract}

キーワード : 加熱ゲル，ゲル物性，水分，スケトウダラすり身，タンパク質，糖

著者らは, 先に水産ねり製品の製造に抢ける肉糊の水 伸ばし処理が，ゲル化製品のテクスチャーに及ぼす影響 について知見を得るため, すり身タンパク質の濃度と肉 糊の加熱ゲル形成能の関連について詳細に検討した。ま たその成果として加熱ゲルの物性值のタンパク質濃度依 存性を調べることによって冷凍すり身の加熱ゲル形成能 を正確に評価できることを明らかにした。1,2)

水伸ばしは, 塩ずり時の肉糊に対して $15 \sim 30 \%$ の水 分または氷を加える工程であるが，加えられた水分は加 熱ゲル中に取り込まれ, 結果として製品は変形に際して 壊れにくいゲル物性となることが知られた。1)な打, 水 伸ばし処理の際には，タンパク質だけにとどまらず，す り身に含まれるその他の各種成分（水分, 糖質, 重合リ ン酸塩）の濃度にも変化をもたらすため, これらの変化 が肉糊の加熱によるゲル化に影響を及ぼす可能性が考え
られる。これまで既に, 冷凍すり身の一般構成成分とし てタンパク質, ${ }^{11}$ 水分, ${ }^{3-5)}$ また添加成分として糖質(6) 打 よび重合リン酸塩7,8)などが, 加熱ゲルの物性值に及ぼ す影響について別々に研究がなされている。本研究で は, 形成される加熱ゲル中に含まれる一般構成成分の濃 度と同加熱ゲルの物性值との関係を詳細に検討した。

\section{材料および方法}

試料 本研究では数種のスケトウダラ Theragra chalcogrammaの冷凍すり身を供試した。Tables 1, 2, 3, 4, 抢よび 6 では SA 級の冷凍すり身を使用しているが, Tables 1, 2 の製品は水分が $74.5 \%$, タンパク質が 16.7 $\%$, 糖質が $7.9 \%, \mathrm{pH}$ は 7.25 , Table 3 の製品は水分 が $74.5 \%$, タンパク質が $17.3 \%$, 糖質が $7.6 \%, \mathrm{pH}$ は 7.32，また Tables 4,6 の製品は水分が $74.6 \%$ ，タンパ

* Tel : 81-152-44-7218. Fax : 81-152-44-7219. Email : surimi@nifty.com 
ク質が $16.7 \%$, 糖質が $8.1 \%, \mathrm{pH}$ は 7.35 の組成および $\mathrm{pH}$ である。また Table 5 では A 級の製品を使用した が，水分が $74.4 \%$, タンパク質が $17.2 \%$, 糖質が $7.9 \%$, $\mathrm{pH}$ は 7.38 で, SA 級の製品と良く近似するものを供試 した。な抢, 調製した二段加熱ゲルの一般成分組成は, それぞれ結果の項において示した。また塩ずり肉(肉糊) に糖質㧍よび重合リン酸塩を追加混合するときはショ糖 （日本甜菜製糖侏）抢よびピロリン酸 $\mathrm{Na}$ とトリポリリ ン酸 $\mathrm{Na}$ の等量混合物（商品名ポリリン酸 $2-\mathrm{D}$, 武田薬 品工業秼）を使用した。

すり身の水伸ばし（加水）処理 前報1)において述べ たように, 冷凍すり身を半解凍した後 10～125\%の水 を添加し, サイレントカッター $(\mathrm{SCP}-2$ 型, 容量 $14 \mathrm{~L}$, 刃 (3 枚) 回転数 $1450 \mathrm{rpm}$, 容器回転数 $6 \mathrm{rpm}$, 侏花 木製作所）で $3.0 \%(\mathrm{w} / \mathrm{w})$ の $\mathrm{NaCl}$ と共に 15 分間塩ず りした（すり上がりの温度は $8^{\circ} \mathrm{C}$ 以下）。また肉糊中の 各種成分の濃度を調節するために水の代わりに粉末状の 糖質, $8 \%$ 糖質水溶液, または $0.3 \%$ 重合リン酸塩溶液 を添加した。

加熱ゲルの調製 肉糊を折径 $48 \mathrm{~mm}$ のポリ塩化ビニ リデン製チューブに充填し, $25^{\circ} \mathrm{C}$ の恒温水槽中でゲル の物性值が最大值に至る数時間にわたって予備加熱し た。この間経時的に一部をとり出し, $90^{\circ} \mathrm{C} て ゙ 30$ 分間加 熱（恒温水槽中）して二段加熱ゲルを調製した。また， 直接 $90^{\circ} \mathrm{C}$ で 30 分間加熱して得たゲルは直加熱ゲルと よぶ。

加熱ゲルの物性と一般成分組成の測定 調製された二 段加熱ゲルは流水で冷却後 $25^{\circ} \mathrm{C}$ で一夜保管後, 直径 30 $\mathrm{mm} \times$ 高さ $25 \mathrm{~mm}$ の円柱状試験片として, レオメー ター（不動工業珠製 NRM2002J）を使用し，直径 5 $\mathrm{mm}$ の球形プランジャー（進入速度 $60 \mathrm{~mm} / \mathrm{min}$ ) で破 断強度（BS；g） と破断凹及（bs； cm）を測定しここ れからゲル剛性 $(\mathrm{Gs}=\mathrm{BS} / \mathrm{bs} ; \mathrm{g} / \mathrm{cm})$ を算出した。そ して予備加熱に伴う BS と Gs の経時的な变化を両值の 相関関係から論ずる方法を採用した。吕）また，調製した 二段加熱ゲルについて, 水分, タンパク質, 食塩打よび 灰分の量と $\mathrm{pH}$ を測定した。10,11) また糖質は, 全体から 水分，タンパク質抢よび灰分量を差し引いて概算した。

\section{結果および考察}

加水によるすり身の加熱ゲル形成能の変化 半解凍し た冷凍すり身を塩ずりするとき加水して肉糊中のすり身 タンパク質の濃度を変化させ，それらの加熱ゲル形成能 を検討した研究成果は先に報じた。1 ここでは先ず SA 級の冷凍すり身に対して加水するときの配合組成，打よ びこれから調製した二段加熱ゲルの一般成分組成と $\mathrm{pH}$ を Table 1 に示す。前報1に打いては, 同じ SA 級の冷 凍すり身を使用して, 肉糊の予備加熱 $\left(25^{\circ} \mathrm{C}\right)$ に伴う
Table 1 Mixing ratio of materials for preparation of saltground meat with large amount of water, and proximate composition and $\mathrm{pH}$ of two-step heated gel formed from it

\begin{tabular}{|c|c|c|c|c|c|}
\hline \multicolumn{2}{|c|}{$\begin{array}{l}\text { Mixing ratio of } \\
\text { materials }(\%)\end{array}$} & \multicolumn{3}{|c|}{$\begin{array}{c}\text { Concentration in heated gel*2 } \\
(\%)\end{array}$} & \multirow{2}{*}{$\mathrm{pH}$} \\
\hline Surimi & Water & Moisture & Protein & Sugar*1 & \\
\hline 100 & 0 & 72.6 & 16.0 & 7.8 & 7.09 \\
\hline 100 & 13 & 75.3 & 14.3 & 7.1 & 7.07 \\
\hline 100 & 29 & 78.0 & 12.6 & 6.1 & 7.08 \\
\hline 100 & 50 & 80.6 & 11.0 & 5.0 & 7.09 \\
\hline 100 & 80 & 83.2 & 9.5 & 4.0 & 7.07 \\
\hline 100 & 125 & 85.2 & 8.6 & 3.0 & 7.07 \\
\hline
\end{tabular}

*1 Sugar content was roughly estimated as $100-($ moisture + protein + ash) by weight.

*2 The concentration of each component was expressed as the content $(\%)$ on the basis of wet weight of the heated gel.

二段加熱ゲルの物性值（BS, bs 抢よび Gs）のそれぞれ の経時的変化を図示したが, 本実験の場合も, ほとんど 同じ結果になったので, あらためて図示しない。ここで は, 加水した肉糊について, 予備加熱 $\left(25^{\circ} \mathrm{C}\right)$ に伴う 二段加熱ゲルの BS と Gs の関係の変化を Fig. 1 (A) に, さらに調製したタンパク質濃度が異なる二段加熱ゲ ルのBSとGsの最大值の関係を Fig. 1(B) に示した。

Table 1 に示すように, SA 級すり身に水分を $13 \sim 125$ \%添加して塩ずりし, 調製した二段加熱ゲル中の水分 は 72.6 から $85.2 \%$ に至る間で増加し, タンパク質濃度 は 16.0 から $8.6 \%$ に至る間で減少し, また糖質濃度は 7.8 から 3.0\% まで減少した。ただし pH は 7.06〜 7.09 の間で，ほとんど一定していた。一方，Fig. 1(A)を見 ると加水でタンパク質濃度が減少すると肉糊の加熱ゲル 形成能は低下すること, すなわち予備加熱に伴って二段 加熱ゲルの BS と Gs は増加するが両值は高い值に達し 難くなる傾向が見られる。なお BS と Gs 值の間には常 に良い正の相関が成立するが, 両值の相関を表す関係直 線はタンパク質濃度の減少に伴って同図中に抢いて左方 に移動する傾向が認められた。以上の事実は, 配合した 水分は全て二段加熱ゲル中に取り込まれ，また加熱ゲル 中の水分量の増加に伴ってそのゲル物性が変わり, 硬さ は減ずるが, 変形により壊れにくい物性になる傾向があ ることを示している。また, タンパク質濃度の異なる二 段加熱ゲルの BS と Gsの最大值の間にも正の良い相関 が成り立つことを, Fig. 1(B)に示したが，この関係直 線は原料とした冷凍すり身の等級（格付け）抢よび加熱 ゲルの種類（二段加熱ゲルと直加熱ゲル）などによって 相違することは既に報じた。 ${ }^{10)}$ ただし本実験で調製した 二段加熱ゲルは, 加水によってタンパク質濃度ばかりで なく, その水分と糖質の濃度もまた相違しているので, これらの要因の中のどれが加熱ゲルの物性に最も大きく 
(A)

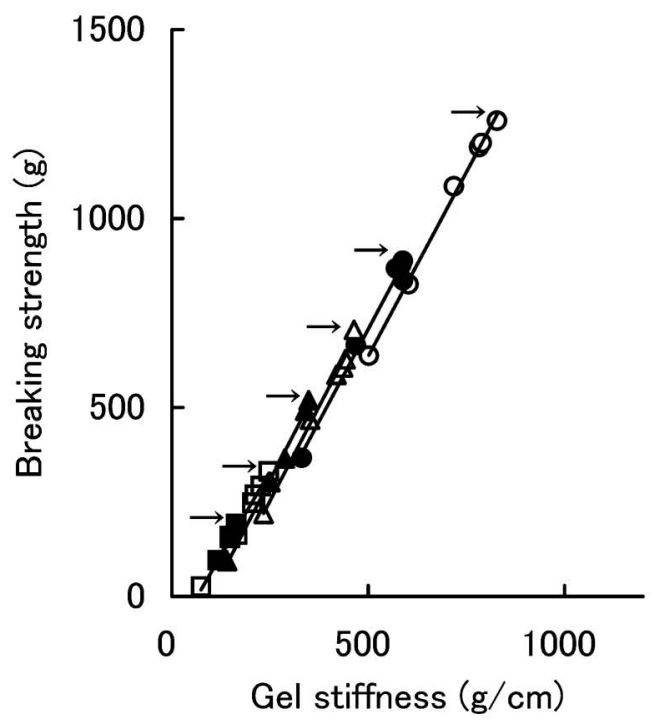

(B)

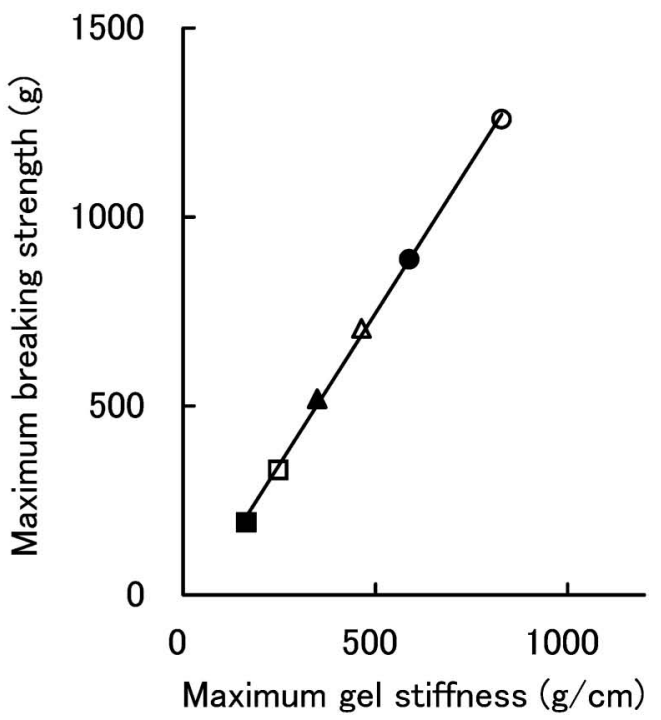

Fig. 1 Change in BS vs Gs plots of two-step heated gels with increasing moisture concentration and relation between maximum values of $B S$ and $G$ s of heated gels.

(A) Change in BS vs Gs plots. The frozen surimi was thawed and ground with 3.0\% $\mathrm{NaCl}$ upon mixing with $0-125 \%$ water as shown in Table 1 . The salt-ground meat was preheated at $25^{\circ} \mathrm{C}$ for several hours, followed by heating at $90^{\circ} \mathrm{C}$ for 30 minutes at appropriate intervals. The two-step heated gel thus formed was subjected to measurement of physical properties (breaking strength (BS) and breaking strain (bs)) with a rheometer using a spherical plunger of $5 \mathrm{~mm}$ in diameter. The moisture concentrations of heated gels were $72.8(\mathrm{O}), 75.3(\bullet), 78.0(\triangle), 80.6(\mathbf{\Delta}), 83.2(\square)$, and $85.2(\boldsymbol{\bullet}) \%$. The protein concentrations of the same gels as above were $16.0(\circ), 14.3(\bullet), 12.6(\triangle), 11.0(\mathbf{\Delta}), 9.5(\square)$, and $8.6(\bullet) \%$. Maximum values of BS and Gs of the heated gels are shown by arrows in the figure.

(B) Relation between maximum values of BS and Gs. Maximum values of BS and Gs of the heated gels are quoted from the data in (A). The moisture concentrations of the two-step heated gels were 72.8 ( ○), $75.3(\bullet), 78.0(\triangle), 80.6(\boldsymbol{\Lambda}), 83.2(\square)$, and 85.2 (-) $\%$.

Table 2 Mixing ratio of materials for preparation of saltground meat with large amount of sugar (ca. 8-53\%), and proximate composition and $\mathrm{pH}$ of two-step heated gel formed from it

\begin{tabular}{|c|c|c|c|c|c|}
\hline \multicolumn{2}{|c|}{$\begin{array}{l}\text { Mixing ratio of } \\
\text { materials (\%) }\end{array}$} & \multicolumn{3}{|c|}{ Concentration in heated gel $(\%)$} & \multirow{2}{*}{$\mathrm{pH}$} \\
\hline Surimi & Sugar*1 & Moisture & Protein & Sugar*2 & \\
\hline 100 & 0 & 72.6 & 16.0 & 7.8 & 7.09 \\
\hline 100 & 13 & 64.5 & 14.3 & 17.8 & 7.12 \\
\hline 100 & 29 & 57.5 & 12.8 & 26.5 & 7.16 \\
\hline 100 & 50 & 50.2 & 11.2 & 35.2 & 7.16 \\
\hline 100 & 80 & 42.0 & 9.4 & 45.4 & 7.20 \\
\hline 100 & 125 & 36.5 & 7.6 & 52.8 & 7.20 \\
\hline
\end{tabular}

*1 Sucrose powder was used.

*2 Sugar content was estimated as in Table 1 .

寄与しているかはここでは断定することができない。

糖質によるすり身の加熱ゲル形成能の変化 SA 級の 冷凍すり身に糖質（ショ糖）粉末を添加するときの配合 組成およびこれから調製した二段加熱ゲルの一般成分と $\mathrm{pH}$ を Table 2 に示した。加糖した肉糊から $25^{\circ} \mathrm{C}$ の予 備加熱で二段加熱ゲルを調製したが，形成される二段加
熱ゲルの物性值は糖質濃度の増加に伴い激減したので, ここでは添加量が $50 \%$ までの加熱ゲルに限って, 予備 加熱に伴う二段加熱ゲルの BS と Gs の関係の変化, ま たタンパク質濃度の異なる加熱ゲルの BS と Gs の最大 值と糖濃度の関係を Fig. 2(A) と（B)に示した。Table 2 の配合によると, 二段加熱ゲルの糖質濃度は 7.8 から 52.8\% に至る間で増加し, 水分は 72.6 から $36.5 \%$ に至 る間で減少し，またタンパク質濃度も 16.0 から $7.6 \%$ に至る間で減少した。 $\mathrm{pH}$ は 7.09〜7.20の間でほとんど 変わらなかった。一方, Fig. 2(A) を見ると糖の添加に よって肉糊の加熱ゲル形成能は低下し, BS と Gs の最 大值は糖質濃度が高くなるほど低值となる傾向を示し た。また両值の間には, いずれの場合も, 良い正の相関 が成り立つが，BS と Gs の関係直線は糖質濃度が高く なるほど同図中で右方に移動する傾向を示している。ま た糖質濃度の異なる二段加熱ゲルの BS と Gs の最大值 の間にも正の良い相関が成立するが，この関係直線も加 水した加熱ゲルが示した同じ関係直線に比べて同図 (Fig. 2(B)) 中で右側に位置している。これらの結果 は，調製した二段加熱ゲルの物性が糖質濃度の増加に伴 って変形に際して壊れ易い（いわば脆い）ものになるこ 
(A)

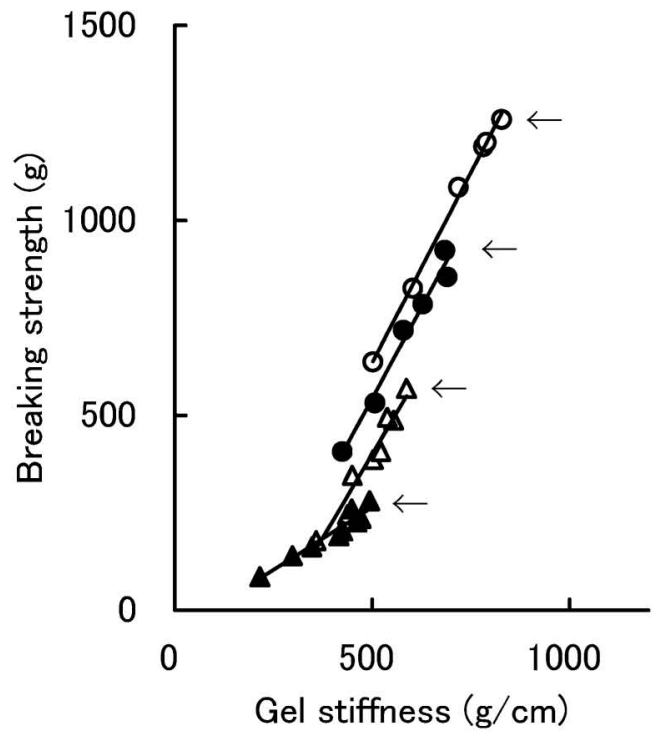

(B)

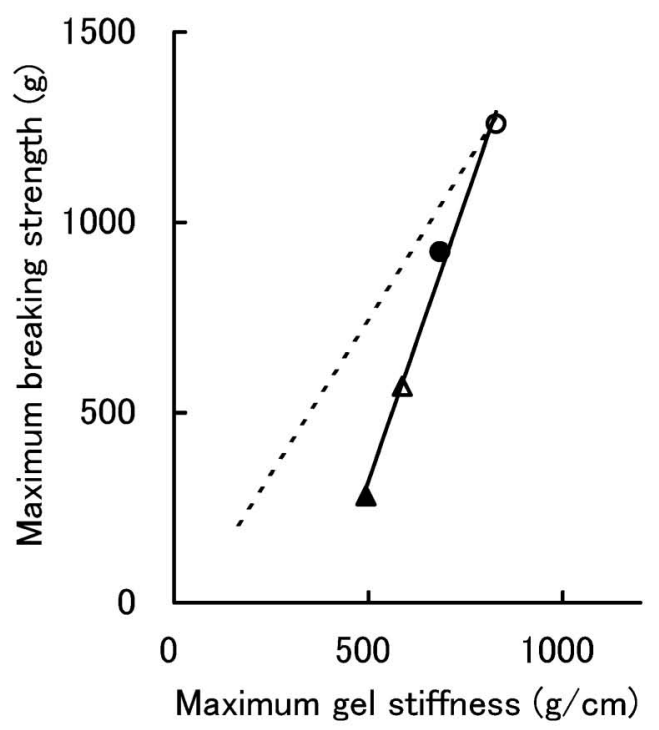

Fig. 2 Change in BS vs Gs plots of two-step heated gels with increasing sugar concentration $(4.8 \rightarrow 35.2 \%)$ and relation between maximum values of $\mathrm{BS}$ and $\mathrm{Gs}$ of heated gels.

(A) Change in BS vs Gs plots. The two-step heated gel was prepared as in Fig. 1, except that 0-125\% sucrose powder was mixed with surimi in place of water as shown in Table 2. The physical properties of the heated gel were measured as also in Fig. 1. The sugar concentrations in the heated gels were $7.8(\mathrm{O}), 17.8(\bullet), 26.5(\triangle)$, and $35.2(\boldsymbol{\Delta}) \%$. Maximum values of BS and Gs of the heated gels are shown by arrows in the figure.

(B) Relation between maximum values of BS and Gs. Maximum values of BS and Gs are quoted from the data in (A). The sugar concentrations of heated gels were $7.8(\mathrm{O}), 17.8(\bullet), 26.5(\triangle)$, and $35.2(\mathbf{\Delta}) \%$. The dotted line shows the relation of maximum values of BS and Gs as a function of moisture concentration (transferred from Fig. 1(B)).

とを示しており，加水による変化とは逆の現象を示し た。加熱ゲル中の構成成分組成（Table 1 と2）を比べ ると，すり身に対して添加混合する水分または糖質（粉 末）が増加するに伴って，いずれの場合も形成される加 熱ゲル中のタンパク質濃度は減少する傾向を示してい る。しかしすり身に対して添加する水分が多いほど加熱 ゲル中の水分は増加するのに，添加する糖質が多いほど 加熱ゲル中の水分は逆に減少する傾向を示している。従 って，水分または糖質の添加に伴って形成される加熱ゲ ルの物性の最大值が，添加量に比例するように減少する のは抢そらくタンパク質濃度の減少に強く依存している ように見える。一方，水分が増加したときに起こる加熱 ゲルの物性変化と糖質を増加したときに起こる加熱ゲル の物性変化の様相が相違している（すなわち糖質の濃度 を増加する場合の方が Gs の減少度合が BS の減少度合 に比べて相対的に大きい) 事実は, 水分に強く関連して いるように見える。ただし調製した加熱ゲル中では，糖 質, 水分とタンパク質の濃度が同時に変動しているの で，どれが大きく影響を及ぼしているのかまだ特定でき ない。

SA 級のすり身に対して水分と糖質粉末を添加すると きの配合組成抢よび調製された二段加熱ゲルの一般成分

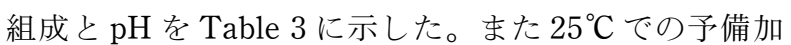

Table 3 Mixing ratio of materials for preparation of saltground meat with large amount of sugar (ca. 6-25\%), and proximate composition and $\mathrm{pH}$ of two-step heated gel formed from it

\begin{tabular}{|c|c|c|c|c|c|c|}
\hline \multicolumn{3}{|c|}{$\begin{array}{c}\text { Mixing ratio of materials } \\
(\%)\end{array}$} & \multicolumn{3}{|c|}{ Concentration in heated gel (\%) } & \multirow{2}{*}{$\mathrm{pH}$} \\
\hline Surimi & Water & Sugar*1 & Moisture & Protein & Sugar*2 & \\
\hline 75 & 25 & 0 & 78.3 & 12.4 & 6.1 & 7.18 \\
\hline 75 & 20 & 5 & 73.9 & 12.4 & 10.4 & 7.18 \\
\hline 75 & 15 & 10 & 68.7 & 12.4 & 15.6 & 7.18 \\
\hline 75 & 10 & 15 & 64.1 & 12.4 & 20.4 & 7.21 \\
\hline 75 & 5 & 20 & 59.1 & 12.4 & 25.4 & 7.21 \\
\hline
\end{tabular}

*1 Sucrose powder was used.

*2 Sugar content was estimated as in Table 1.

熱に伴う二段加熱ゲルの BS と Gsの関係の変化を Fig. 3(A)に示した。Table 3 に示したように，ここではす り身に対して $1 / 3$ 量の水分を添加した場合を対照と し，この水分量の一部をショ糖粉末で代替する配合組成 とした。これによると, 肉糊中のすり身タンパク質濃度 は, 糖質濃度に関わりがなく同值となり, 形成された加 熱ゲルのタンパク質濃度も一定で， $12.4 \%$ になった。 しかし水分は 78.3 から $59.1 \%$ に至る間で減少し, また 糖質濃度は 6.1 から $25.4 \%$ に至る間で増加した。なお $\mathrm{pH}$ は 7.18〜 7.21 で大きな変動は見られなかった。一 
(A)

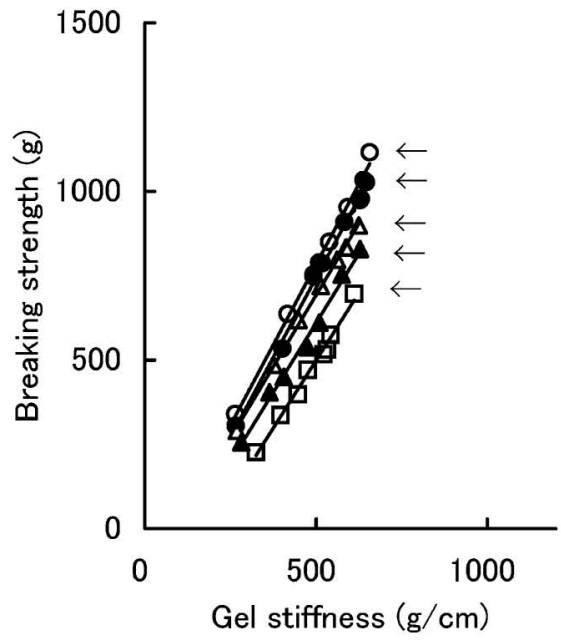

(B)

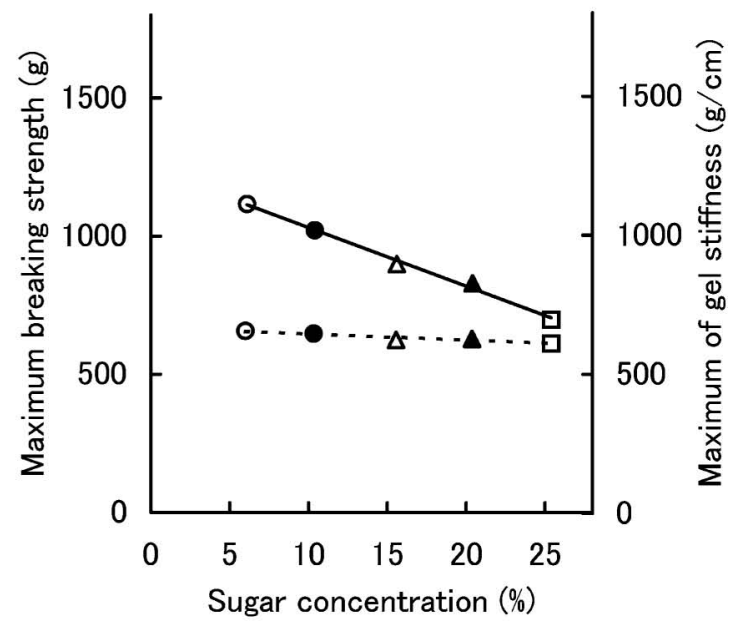

Fig. 3 Change in BS vs Gs plots of two-step heated gels with increasing sugar concentration $(6.1 \rightarrow 25.4 \%)$ under a fixed protein concentration and sugar concentration dependence of maximum values of BS and Gs of heated gels.

(A) Change in BS vs Gs plots. The two-step heated gel was prepared as in Fig. 1, except that the water was replaced with sucrose powder as shown in Table 3. The physical properties of the heated gel were measured as also in Fig. 1. The sugar concentrations in the heated gels were $6.1(\circ), 10.4(\bullet), 15.6(\triangle), 20.4(\mathbf{\Delta})$, and $25.5(\square) \%$. The protein concentration was fixed to $12.4 \%$ of all the heated gels. Maximum values of BS and Gs of the heated gels are shown by arrows in the figure.

(B) Sugar concentration (6.1-25.4\%) dependence of maximum values of BS $(-)$ and Gs ( .....). Maximum values of BS and Gs are quoted from the data in (A). The moisture concentrations of two-step heated gels were $78.3(\mathrm{O}), 73.9(\bullet), 68.7(\triangle)$, $64.1(\mathbf{\Lambda})$, and 59.1 ( $\square) \%$, respectively.

方，予備加熱に伴って形成される二段加熱ゲルの BS と Gs の変化の関係はFig. 3(A)に示したが，これによる と BS と Gs 值の間には加熱ゲル中の糖質濃度に関わり ない正の良い相関が成立した。また BS の最大值は糖質 濃度が高いほど低い値になる傾向を示したが，Gsの最 大值は糖質濃度に関わりなく, ほぼ一定の值となる事実 が認められた。なお BS と Gs の関係直線は, 糖質濃度 が高いほぞ同図中の右側に移動して位置する傾向を示し たが，これの結果は，先に示した糖質粉末を添加した実 駼結果と同じである。それゆえ，糖質を加えた加熱ゲル の BS が減少するのは, 加熱ゲル中のタンパク質濃度の 減少にのみ依存しているのではなく，水分の減少，また は糖質濃度の増加のいずれかの影響をも受けた結果であ ると推定される。実際に二段加熱ゲルの BS の最大值と 糖質濃度との間には Fig. 3(B) に示すように負の良い相 関が見られる。しかし加熱ゲル水分量と糖質濃度との間 にも良い負の相関が認められる（ここには図示しない） ので，物性変化の直接の原因は未だ特定できない。な お，先に Fig. 2 に示した実験においては，形成された 二段加熱ゲル中の糖質濃度が増加するに伴って BS の最 大值ばかりでなく Gs の最大值もまた減少する事実が示 されているが，これは Fig. 3 の実験の場合と異なり， 糖質濃度の増加に伴って加熱ゲル中のタンパク質濃度が 同時に減少する場合である。従って糖質を追加して調製 する加熱ゲルでは，Gsの最大值は，タンパク質濃度に
依存して定まり，糖質濃度には関わりがないが，一方 BS の最大值は糖質濃度または水分にも影響されている ことが確認される。しかし，そのいずれであるかは未だ 不明である。

タンパク質濃度を一定にした本実験の場合，添加する 糖質の単位濃度, $1 \%$ 当たり BS として $20 \mathrm{~g}$ の減少 （損失）が起こるという結果となった。Table 2 および 3 に示した配合組成の肉糊から調製される二段加熱ゲルで は，糖質濃度が $10 \%$ から $30 \%$ に及ぶが，この濃度は 通常の冷凍すり身の糖質濃度に比べればかなりの大過剩 に相当する。そこで，すり身に対してあらたに添加する 糖質量を減らして, 加熱ゲル中の濃度が $8 \sim 12 \%$ とな るような配合組成を工夫した。Table 4 には，その配合 組成と調製された二段加熱ゲルの一般成分組成と性状を 示した。また肉糊から $25^{\circ} \mathrm{C}$ の予備加熱で形成される二 段加熱ゲルの BS と Gs の関係の変化を Fig. 4(A) に示 した。Table 4 によると，形成される二段加熱ゲルのタ ンパク質濃度はほぼ一定で $15.2 \sim 15.5 \%$, 糖質濃度は 7.7 から 12.1\%の間, 水分量は 73.7 69.1\%の狭い範 囲内のものになった。また $\mathrm{pH}$ も 7.24〜 7.27でほとん ぞ同じになった。一方, 予備加熱に伴い形成される二段 加熱ゲルの BS と Gs 值の変化の関係（Fig. 4 (A)）を見 ると, その関係直線の同図中での位置は, 糖質濃度が高 いほど右側に移動する傾向があることを認めたが，その 差は極めて小さかった。また糖質濃度の異なる加熱ゲル 
の BS と Gs の最大值と加熱ゲル中の糖質濃度の関係を

Fig. 4(B)に示したが，この濃度範囲では形成される二 段加熱ゲルの物性は極めて良く近似することが示され た。この事実は, 冷凍すり身の等級（格付け）による糖 質濃度の差 $(5 \sim 8 \%)$ や, 水伸ばし $(1 / 3 \sim 1 / 2$ 量の加 水）によって生ずる肉糊の糖濃度の差異が, 肉糊の加熱 ゲル形成能に対して及ぼす影響は大きなものでないこと を示すものである。

糖質の濃度減少によるすり身の加熱ゲル形成能の変化 水伸ばし処理においては, 肉糊中の糖質濃度は $1 / 3 \sim 1 /$ 2 に希釈されることになる。そこで添加する水分の代わ

Table 4 Mixing ratio of materials for preparation of saltground meat with large amount of sugar (ca. 8-12\%), and proximate composition and $\mathrm{pH}$ of two-step heated gel formed from it

\begin{tabular}{|c|c|c|c|c|c|c|}
\hline \multicolumn{3}{|c|}{$\begin{array}{c}\text { Mixing ratio of materials } \\
(\%)\end{array}$} & \multicolumn{3}{|c|}{ Concentration in heated gel $(\%)$} & \multirow{2}{*}{$\mathrm{pH}$} \\
\hline Surimi & Water & Sugar*1 & Moisture & Protein & Sugar*2 & \\
\hline 100 & 5 & 0 & 73.7 & 15.2 & 7.7 & 7.24 \\
\hline 100 & 4 & 1 & 72.5 & 15.2 & 8.9 & 7.25 \\
\hline 100 & 3 & 2 & 71.8 & 15.2 & 9.4 & 7.26 \\
\hline 100 & 2 & 3 & 70.9 & 15.2 & 10.2 & 7.27 \\
\hline 100 & 1 & 4 & 69.9 & 15.2 & 11.4 & 7.25 \\
\hline 100 & 0 & 5 & 69.1 & 15.2 & 12.1 & 7.25 \\
\hline
\end{tabular}

*1 Sucrose powder was used.

*2 Sugar content was estimated as in Table 1.
りに $8 \%$ ショ糖溶液を添加すれば形成される加熱ゲル 中のタンパク質濃度と水分には大きな差を生ずることな く, 糖質濃度だけが異なるような配合になる筈である。 そのための配合組成と調製された加熱ゲル中の一般成分

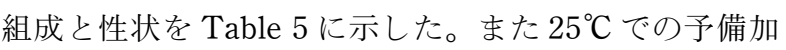
熱に伴う二段加熱ゲルの BSと Gs 值の関係の変化を Fig. 5 に示した。Table 5 によると, 調製された加熱ゲ ルはタンパク質濃度と水分がほぼ同じで糖質濃度が 5.8 と $7.7 \%$ ， また 3.7 と $7.6 \%$ と異なる加熱ゲルが調製さ れたが， $25^{\circ} \mathrm{C}$ での予備加熱に伴う二段加熱ゲルの BS と Gs の関係の変化, および $\mathrm{BS}$ と Gs の最大值は極め

Table 5 Mixing ratio of materials for preparation of saltground meat with small amount of sugar, and proximate composition and $\mathrm{pH}$ of two-step heated gel formed from it

\begin{tabular}{|c|c|c|c|c|c|c|}
\hline \multicolumn{3}{|c|}{$\begin{array}{l}\text { Mixing ratio of materials } \\
(\%)\end{array}$} & \multicolumn{3}{|c|}{ Concentration in heated gel $(\%)$} & \multirow{2}{*}{$\mathrm{pH}$} \\
\hline Surimi & Water & Sugar*1 & Moisture & Protein & Sugar*2 & \\
\hline 100 & 0 & 0 & 72.3 & 16.5 & 7.5 & 7.18 \\
\hline 75 & 25 & 0 & 78.1 & 12.5 & 5.8 & 7.18 \\
\hline 75 & 0 & 25 & 76.4 & 12.3 & 7.7 & 7.18 \\
\hline 50 & 50 & 0 & 84.2 & 8.7 & 3.7 & 7.14 \\
\hline 50 & 0 & 50 & 80.6 & 8.4 & 7.6 & 7.14 \\
\hline
\end{tabular}

*1 $8 \%$ sucrose in aqueous solution was used.

*2 Sugar content was estimated as in Table 1 .

(A)

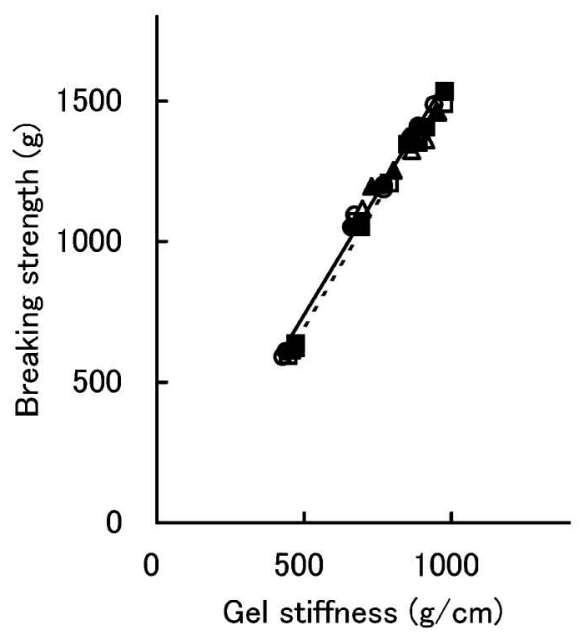

(B)

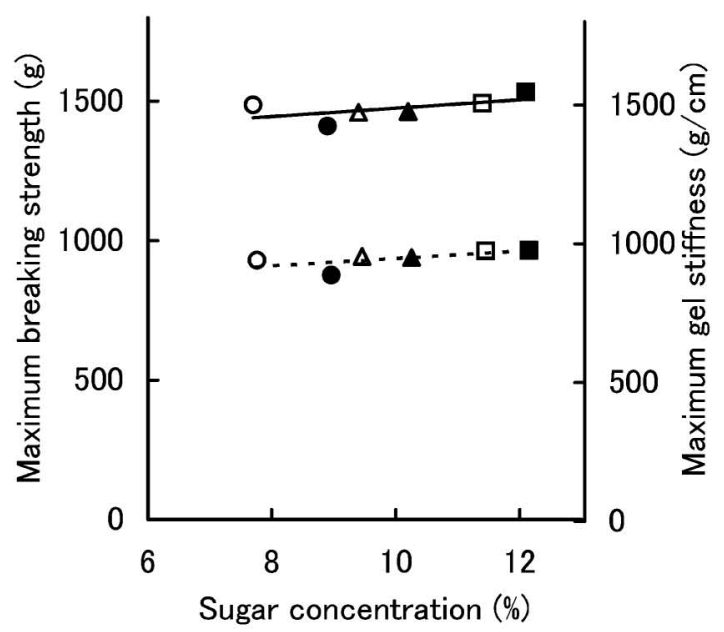

Fig. 4 Change in BS vs Gs plots of two-step heated gels with increasing sugar concentration $(7.7 \rightarrow 12.1 \%)$ under a fixed protein concentration and sugar concentration dependence of maximum values of BS and Gs of heated gels.

(A) Change in BS vs Gs plots. The two-step heated gel was prepared as in Fig. 1, except that the water was replaced with $30 \%$ sucrose solution as shown in Table 4. The physical properties of the heated gel were measured as also in Fig. 1. The sugar concentrations in the heated gels were $7.7(\circ), 8.9(\bullet), 9.4(\triangle), 10.2(\Delta), 11.4(\square)$ and $12.1(\cdots-\cdots) \%$. The protein concentration of all heated gels was fixed to $15.2-15.5 \%$.

(B) Sugar concentration dependence of maximum values of BS (- - and Gs (-...-) of two-step heated gel under a fixed protein concentration. Maximum values of BS and Gs are quoted from the data in (A). The moisture concentrations of the heated gels were $73.7(\circ), 72.5(\bullet), 71.8(\triangle), 70.9(\mathbf{\Delta}), 69.9(\square)$ and $69.1(\bullet) \%$. 


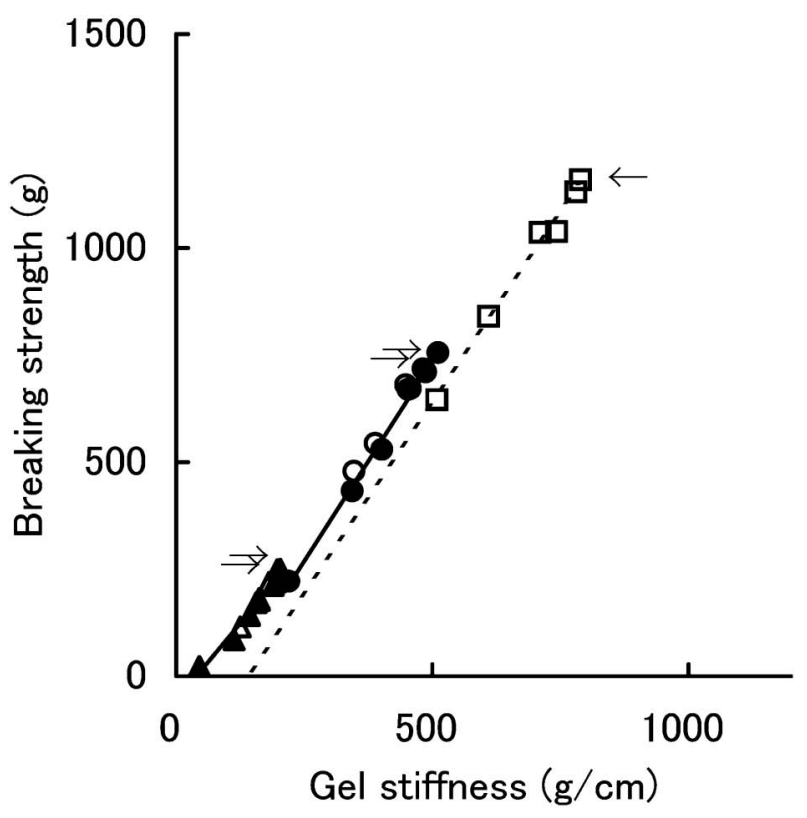

Fig. 5 Change in BS vs Gs plots of two-step heated gel with reducing sugar concentration $(7.7 \rightarrow 3.7 \%)$. The two-step heated gel was prepared as in Fig. 1, except that the water was replaced with $8 \%$ sucrose solution as shown in Table 5. The physical properties of the heated gel were measured as also in Fig. 1. The sugar concentrations in the heated gels were $7.7(\mathrm{O}), 5.8$ $(\bullet), 7.6(\triangle), 3.7(\Delta)$ and 7.5 of original $(\cdots \square \cdots) \%$. The protein concentrations in the heated gels were $12.5(\bigcirc), 12.3(\bullet), 8.7(\triangle)$ and $8.4(\bullet) \%$. Maximum values of BS and Gs are shown by arrows in the figure.

て良く近似することが確かめられた。これによって水伸 ばしによる肉糊の加熱ゲル形成能の低下は，すり身タン パク質濃度の減少による影響が極めて大きく, 糖質濃度 の減少にはほとんど影響されないことが明らかである。 なお肉糊に糖質粉末を添加する場合は加熱ゲル中の水分 （水分の相対的な濃度）が減少する。また高濃度の糖質 溶液を添加する場合も加熱ゲル中の水分は, やはり減少 することになる。そして低濃度の糖質溶液を添加する場 合だけは，水分が多い加熱ゲルを調製することが可能で あり，またこのときは，予備加熱に伴う二段加熱ゲルの BS と Gs の変化に関わる関係直線は同図中で左側に位 置するようになることを認めた。これは，加熱ゲル中の 水分とタンパク質の濃度の両方の調節が製品のゲル物性 に強い影響を及ぼすこと，両成分の濃度が設定されてい れば，糖質（特に $8 \%$ 以下の低濃度域）の影響は極め て小さく無視できるほどであることを示すものである。

重合リン酸塩の濃度減少によるすり身の加熱ゲル形成 能の変化 肉糊を水伸ばしするときは, すり身に含まれ ている糖質ばかりでなく, 重合リン酸塩（PP 塩）の濃 度も減少する。そこで PP 塩濃度の減少がすり身の加熱
Table 6 Mixing ratio of materials for preparation of saltground meats with small amount of $\mathrm{Na}-\mathrm{PP}$, and proximate composition and $\mathrm{pH}$ of two-step heated gel formed from it

\begin{tabular}{|c|c|c|c|c|c|c|}
\hline \multicolumn{3}{|c|}{$\begin{array}{c}\text { Mixing ratio of materials } \\
(\%)\end{array}$} & \multicolumn{3}{|c|}{ Concentration in heated gel (\%) } & \multirow{2}{*}{$\mathrm{pH}$} \\
\hline Surimi & Water & $\mathrm{Na}-\mathrm{PP} * 1$ & Moisture & Protein & $\mathrm{Na}-\mathrm{PP}^{* 2}$ & \\
\hline 75 & 25 & 0 & 78.3 & 12.2 & $(0.20)$ & 7.18 \\
\hline 75 & 0 & 25 & 78.4 & 12.2 & $(0.30)$ & 7.18 \\
\hline 50 & 50 & 0 & 84.8 & 8.1 & $(0.13)$ & 7.14 \\
\hline 50 & 0 & 50 & 84.7 & 8.1 & $(0.30)$ & 7.14 \\
\hline
\end{tabular}

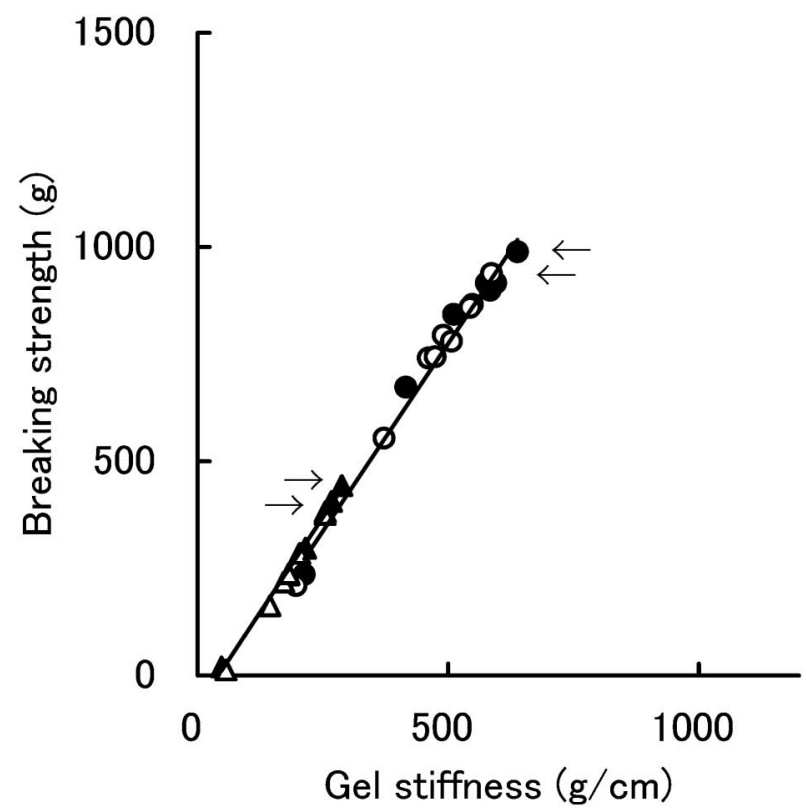

Fig. 6 Change in BS vs Gs plots of two-step heated gel with reducing Na-polyphosphate concentration. The two-step heated gel was prepared as in Fig. 1, except that the water was replaced with $0.3 \% \mathrm{Na}$ polyphosphate ( $\mathrm{pH} 7.0$ with $\mathrm{HCl}$ ) as shown in Table 6 . The physical properties of the heated gel were measured as also in Fig. 1. The Na-polyphosphates concentrations in the salt-ground meat were $0.30(\mathrm{O})$, $0.20(\bullet), 0.30(\triangle)$, and $0.13(\boldsymbol{\Delta}) \%$. The protein concentrations in the heated gels were fixed to $12.2(\mathrm{O}$, - ) or to $8.1(\triangle, \mathbf{\Delta}) \%$. Maximum values of BS and Gs are shown by arrows in the figure.

ゲル形成能に及ぼす影響についても調べた。ここでは市 販の PP 塩製剂を供試したが，肉糊の $\mathrm{pH}$ が異常に上昇 することを防ぐために少量の $\mathrm{HCl}$ を加えて $\mathrm{pH}$ を 7 に 調節した $0.3 \%$ 水溶液を使用した。すり身と水分および PP 塩溶液の配合組成, およびこれから調製した二段加 熱ゲルの一般成分組成と pH を Table 6 に示した。また $25^{\circ} \mathrm{C}$ での予備加熱に伴う二段加熱ゲルの BS と Gs の関 
Table 7 Proximate composition (and $\mathrm{pH}$ ) of frozen surimi and two-step heated gel formed from it

\begin{tabular}{|c|c|c|c|c|c|c|c|c|}
\hline & \multicolumn{4}{|c|}{ Frozen surimi (Grade) } & \multicolumn{4}{|c|}{ Two-step heated gel } \\
\hline & Moisture\% & Protein\% & Additive $^{* 2}$ & $\mathrm{pH}$ & Moisture\% & Protein\% & Additive ${ }^{* 2}$ & $\mathrm{pH}$ \\
\hline \multirow{3}{*}{$(\mathrm{SA}) * 1$} & 74.5 & 16.7 & 8.8 & 7.25 & 72.6 & 16.0 & 8.4 & 7.09 \\
\hline & 74.5 & 16.9 & 8.6 & 7.32 & 72.3 & 16.2 & 8.5 & 7.13 \\
\hline & 74.6 & 16.7 & 8.7 & 7.35 & 72.4 & 16.2 & 8.4 & 7.20 \\
\hline$(\mathrm{A}) * 1$ & 74.4 & 17.2 & 8.4 & 7.38 & 72.3 & 16.5 & 8.3 & 7.18 \\
\hline
\end{tabular}

*1 (SA), (A) : Grade of frozen surimi on the market

*2 Additive : Sugar + Na-polyphosphate

係の変化をFig. 6 に示した。すり身中のPP 塩は, 塩ず り抢よび加熱ゲル化の過程で酵素分解されるので，その 成分組成を分析することは余り意味がない。12,13) そこ で，ここではすり身との配合組成のみを明示した。 Table 6 によると, 調製された加熱ゲル中の水分量とタ ンパク質濃度はほとんど同じなので, PP 塩の添加濃度 が 0.20 と $0.30 \%$ ，打よび 0.13 と $0.30 \%$ と異なる製品

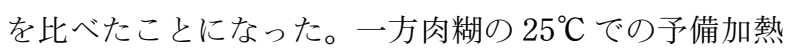
に伴う二段加熱ゲルの BS と Gs の間には良い正の相関 があるが，両值の関係直線は PP 塩の濃度に関わりな く, 全ての加熱ゲルで良く合致した。かつ, 加熱ゲルの BS と Gs の最大值も両加熱ゲルの間で近似することを 認めた。加熱ゲル中に配合される PP 塩の濃度はすり身 に対して $1 / 3 \sim 1 / 2$ 量の加水をしたときに相当している が，この差異は加熱ゲル形成能に対して大きな影響を及 ぼしていないことを示す結果であった。

冷凍すり身と加熱ゲル中の一般成分組成と性状 本研 究では, 加熱ゲル中の水分, タンパク質, 糖質, 抢よび 重合リン酸塩の濃度（および $\mathrm{pH} ）$ と, 当該加熱ゲルの 物性との関係から冷凍すり身各構成成分の加熱ゲル形成 に及ぼす影響を検討したが，そのためすり身に対して水 分, 糖質などの成分を追加, または加水により希釈して 加熱ゲルを調製した。実験に使用した冷凍すり身は SA 級と A 級であるが，これらから調製した加熱ゲルと冷 凍すり身原料の間で比較すると, Table 7 に示すよう に, 加熱ゲル中の成分含量は, $3.0 \%$ の食塩を加えた結 果として水分で $1.9 \sim 2.2 \%$, タンパク質濃度で $0.5 \sim 0.7$ $\%$, 糖質など添加物で $0.1 \sim 0.4 \%$ 低值となり, $\mathrm{pH}$ も 0.16〜0.20 低值となっていた。また Table 1 から 6 に 示した配合組成の原料から形成された加熱ゲル中の一般 成分組成は，いずれも，その配合からほぼ計算で求めら れると抢りの值になることを認めた。すなわち本研究で 使用した SA 級 (一部 A 級) の冷凍すり身から, 水分 は 59.0 85.0\%, タンパク質濃度は 8.6 16.0\%, 糖質 濃度は 3.0 35.2\%（52.8\% まで検討）, 重合リン酸塩 濃度は $0.13 \sim 0.3 \%$ にわたる組成の加熱ゲルが調製さ
れ, 本研究に抢ける比較検討の対象となっている。それ ゆえ, 加熱ゲル中の一般成分組成と $\mathrm{pH}$ は, 冷凍すり身 に添加する水分や各種成分（糖質など添加物）の配合組 成を基に計算によって求められるので, その結果から加 熱ゲル化製品のテクスチャーを設計する技術の開発に利 用できると考えられる。

\section{文献}

1) 北上誠一, 村上由里子, 安永廣作, 加藤 登, 新井健 一、スケトウダラ冷凍すり身タンパク質のゲル形成能と その濃度依存性. 日水誌 2005; 71: 957-964.

2）北上誠一、スケトウダラ冷凍すり身のゲル形成能に関わ 万基礎的研究. 博士論文, 酪農学園大学, 江別. 2006; 89-103.

3) Chen HH, Lee YC. Effects of water content and chopping method on the physical properties of surimi and kamaboko. Fish. Sci. 1997; 63: 755-761.

4) Chen HH. The effect of settig on the physical properties of surimi and kamaboko under various water content and chopping methods. Fish. Sci. 1997; 63: 762-768.

5）山澤正勝, 戸谷精一, 杉本勝之, 村瀬 誠, 加藤丈雄, 志賀一三. 坐りに及ぼす原料肉水分および $\mathrm{pH}$ の影響に ついて. 愛知県食工試年報 1982; 23: 75-82.

6）船津保浩, 細川一, 南部正一, 新井健一. スケトウダ ラ肉糊のゲル形成能とミオシン重鎖の多量化に及ぼすり ルビトールの影響. 日水誌 1993; 59: 1599-1607.

7）松川雅化, 平田史生, 木村省二, 新井健一. スケトウダ ラ坐り一加熱ゲルのゲル物性に及ぼすピロリン酸塩の効 果. 日水誌 1996; 62: 94-103.

8）山口敦子, 阿部洋一, 石下真人, 鮫島邦彦, 新井健一. 凍結貯蔵中のスケトウダラ冷凍すり身のゲル形成能に及 ほす重合リン酸塩の効果. 日水誌 2000; 66: 481-488.

9）北上誠一, 阿部洋一, 村上由里子, 安永廣作, 加藤 登, 新井健一. 水産敉り製品の製造に抢ける坐りと戻り の効用. New Food Industry 2003; 45: 24-32.

10）西岡不二男. 冷凍すり身の品質検查基準. 日水誌 1994; 60: $282-283$.

11）柴 真. 水産ねり製品の製造.「水産ねり製品入門」日 本食糧新聞社, 東京. $2002 ; 126-130$.

12）松永明信, 大泉 徹, 山本 敦, 川崎賢一, 水上英一 魚肉ねり製品の製造工程に抢けるポリリン酸塩の消長. 日水誌 1990; 56: 2077-2082.

13）松永明信. 魚肉中のリン酸化合物及びリン酸塩の分析並 びに食品製造工程中における挙動に関する研究. 食衛誌 2000; 41: 267-270. 